\title{
Accounting
}

\section{Specialist tenure of audit partner and audit quality}

\section{Zaenal Fanania ${ }^{*}$, Virmey Mustika Fitriya Budia and A. A. Gde Satia Utama ${ }^{a}$}

${ }^{a}$ Accounting Department, Economic and Business Faculty, Universitas Airlangga, Surabaya, Indonesia

\begin{tabular}{l}
\hline C H R O N I C L E \\
\hline Article history: \\
Received: December 3, 2021 \\
Received in revised format: \\
December 302020 \\
Accepted: January 3, 2021 \\
Available online: \\
January 4, 2021 \\
\hline Keywords: \\
Audit Quality \\
Seasoned \\
Unseasoned \\
Audit partner \\
Discretionary accrual \\
\hline
\end{tabular}

\section{A B S T R A C T}

This study aims to determine the ability of the audit quality provided by audit partners to be influenced by seasoned and unseasoned specialists using the Ordinary Least Square (OLS) regression method and discretionary loan loss provision (DLLP). This study shows that the audit quality provided by a specialist partner auditor is higher than the non-specialist. Furthermore, after classifying the specialist partner auditors as seasoned and unseasoned, the results showed that the audit quality provided by seasoned specialist partner auditors is higher than the non-specialist. While the audit quality provided by the unseasoned specialist partner auditor is almost the same as those provided by the non-specialist. This study contributes to literature on specialist auditors. The longer the audit partner is classified as a specialist, the higher the audit quality. Therefore, it can improve the quality of financial statements.

\section{Introduction}

(C) 2021 by the authors; licensee Growing Science, Canada

DeAngelo (1981) defined audit quality as the probability of an auditor to detect and disclose violations committed by clients in their accounting system. It is important to note that this definition is associated with competent and independent auditors conducting quality audits. Competence refers to auditors' ability to determine material misstatement in a financial statement. In contrast, independence refers to their courage in reporting fraud. A prolonged timeframe can increase the auditor's ability to understand the client's industry, thereby improving their ability to detect misstatements. Pramaswaradana and Astika (2017) stated that auditors repeatedly acquire particular expertise or specialization in auditing the same company. Auditors carry out industry specialization by increasing their expertise in particular industry fields or selecting market shares focused on specific industries (Nizar, 2017). The specialization of auditors in specific industries makes them acquire sufficient knowledge of that particular company (Pramaswaradana and Astika, 2017). Garcia-Blandon and Argiles-Bosch (2018) stated that industry specialist auditors are generally determined based on market share, calculated using different metrics, such as audit fees, total assets, and sales revenue. Furthermore, Romanus et al. (2008) reported that specialist auditors are believed to have good report quality to detect information accurately. Meanwhile, Bae et al. (2018) stated that auditors specialized in the industry provide high audit quality at lower costs through efficiency gains due to a large amount of knowledge. Studies related to audit quality started developing since the emergence of the scandal by Enron in 2002. Several studies were carried out to discuss the factors influencing the audit quality, mandatory auditor rotations, and changes (Arthur et al., 2017; Bowlin et al.,2015; Febrianto et al., 2017; Idawati, 2014; Siregar \& Elissabeth, 2018). The longer the client's audit engagement period, the higher the quality (Nadia, 2016; Siregar \& Elissabeth, 2018). However, studies carried out by Paramita \& Latrini (2015) and Pramaswaradana and Astika(2017)stated that there are

* Corresponding author

E-mail address: fanani@,feb.unair.ac.id (Z.Fanani) 
negative influences of audit tenure on quality. Some of the other factors that improve audit quality, according to previous studies, are auditor's reputations, fee, competence, motivation, and specialization (Nadia, 2016; Idawati, 2014).

This research is essential because it develops a specialist auditor measurement model using a study carried out by Gaver and Utke (2018), which classifies specialist auditors into seasoned and unseasoned. The auditor specialist variable was examined several by evaluating the KAP market share. However, Gaver and Utke (2018) stated that a dominant market share is not an appropriate way to measure auditor specialists because they need two to three years to become specialists. Therefore, Gaver and Utke (2018) tried to develop the auditor specialist model into seasoned and unseasoned specialist auditors. Furthermore, this study classified specialist tenure at the Audit Partner (AP) level with the same criteria as the previous study carried out by Gaver and Utke (2018) to indicate specialists in a particular industry. In recent years, the importance of individual auditors in determining audit quality has received increasing attention. According to former SEC Commissioner Steven Wallman, in assessing auditors' independence, the focus needs to be on individuals, offices, and other company units that determine specific clients' audit decisions (Gul et al., 2013). Individual auditors also play essential roles in the decision-making process in terms of risk preferences, experience, and incentives, significantly influencing audit quality (Nelson \& Tan, 2005). The DLLP used in this research was following Kanagaretnam et al. (2004) study. Beatty and Liao (2014) stated that loan loss provision is an essential accrual for bank performance because it estimates credit losses while reflecting the information asymmetry widely used in various banking literature. This study does not measure audit quality using restatement and concern opinion, such as the previous studies, because these measurements require large samples due to their rare occurrence (Jiang et al., 2018) and low test power (DeFond \& Zhang, 2014; Gaver \& Utke, 2018). This study utilized a small sample without audit fees because not all companies publish their financial statements. The research also failed to utilize the beating and meeting profit benchmarks because audit adjustments do not affect earnings discontinuity (Lennox et al., 2016).

The Ordinary Least Square (OLS) method was used to test the proposed hypothesis using 80 audit partners that signed the financial statements of companies listed on the Indonesian stock exchange's financial services industry. This is consistent with the study carried out by Minutti-Meza (2013), which stated that market share is not a reliable measure of specialists. The regression coefficient between specialists and audit quality was used to indicate a low significance. This study also supports the previous research on audit specialist tenure, which was first developed by Gaver and Utke (2018). The research categorized auditors as specialists in the long term with higher audit quality than non-specialist auditors. This is because the longer the auditor audits in a particular industry, the more competent their techniques. Furthermore, this is similar to the research results, which show that the audit quality provided by unseasoned specialist auditors is similar to the non-specialist auditors. This is because it takes 3 years to become an experienced specialist, whereas and during this waiting time, the quality of the result is the same as a non-specialist auditor.

This research's contribution to the company is associated with the management of specialists and non-specialist auditors' audit quality. Therefore, the management is opportune to choose qualified auditors to produce good financial statements. For the academic world, this research is expected to provide a reference for further development with the result used to evaluate the quality of auditors' services to companies listed on the Indonesia Stock Exchange, especially in the banking industry.

\section{Research hypotheses}

\subsection{Audit Partner Specialist and Audit Quality}

Specialist auditors have more knowledge of a particular industry than non-specialist auditors. This knowledge is obtained during the timeframe. They provide audit services to clients by studying business processes in a particular industry (Balsam et al., 2003; Kamath et al., 2018). Kwon et al. (2017) stated that this knowledge improves the quality of audits produced because auditors utilize audit procedures appropriate to the industry to reduce the possibility of misstatements. Specialist auditors can improve efficiency and effectiveness in determining clients' financial statements' reliability and estimation, thereby enabling them to detect mistakes made by clients in the industry. Therefore, specialist auditors tend to make fewer mistakes compared to non-specialist auditors. (Fitriany et al., 2015; Solomon et al., 1999). Auditors that specialize in particular industries are more confident in determining inherent risk with a higher ability to detect errors and financial fraud (Fitriany et al., 2015). A study carried out by Fitriany et al. (2015) on non-financial companies in Indonesia stated that specialist auditors improve audit quality with a rise in independence and competence. Jensen and Meckling (1976) reported two ways to reduce managers' opportunity to carry out detrimental actions on a company's owner, including outside investors, by monitoring and managing the bonding limit. In the context of this agency theory, specialist auditors have also considered a means to monitor and align the interests of managers and company owners to reduce agency expenditure. Specialist auditors play a significant role in monitoring mechanisms due to their competence and ability to detect misstatements frequently carried out by managers in the industry. Therefore, this makes managers afraid to commit fraud in order to produce a more qualified financial statement. The more quality financial statements provided 
by managers show the high audit quality provided by specialist auditors. Therefore, based on the above explanation, the following hypothesis was formulated:

\section{$\mathrm{H}_{1}$ : The audit quality provided by specialist auditors is higher than non-specialist auditors.}

\subsection{Audit Partner Specialist Tenure and Quality Audit}

Gaver and Utke (2018) stated that the auditor's market shared in an industry is a determinant measure of incomplete audit specialization. This is because the importance of the period needed to create an industry specialization is ignored when analyzed. Audit specialization is an ongoing process, which in practice is developed and validated continuously, through the auditor's experience (Gendron et al., 2007). Gaver and Utke (2018) classified specialist auditors into two groups, namely seasoned and unseasoned specialists. They stated that the audit quality by unseasoned specialist auditors is lower than non-specialist and seasoned auditors. This is because the auditor requires 2 to 3 years to become seasoned, while the quality of the resulting audit is almost the same as a non-specialist. The agency theory discusses managers' and shareholders' interests as agents and principals, although this definition is often contradictory. This is triggered by managers' moral hazard, which makes them tend to carry out activities that benefit themselves and neglect shareholders' interests. Therefore, to avoid this conflict, shareholders can monitor managers' actions by presenting competent auditors. The longer the auditor audits an industry, the more knowledge and competencies they acquire. This makes the auditor an industry specialist with the ability to produce higher quality audit services. Besides selecting specialist auditors, shareholders can improve monitoring by presenting auditors categorized as specialists for an extended period or referred to as seasoned specialist auditors. The services of seasoned and unseasoned specialist auditors are expected to provide better audit quality than non-specialist auditors. Therefore, based on the explanation above, the following hypothesis was formulated:

$\mathrm{H}_{2}$ : The audit quality provided by seasoned specialist auditors is higher than non-specialist auditors.

$\mathrm{H}_{3}$ : The audit quality provided by unseasoned specialist auditors is higher than non-specialist auditors.

$\mathrm{H}_{4}$ : The audit quality provided by seasoned specialist auditors is higher than unseasoned auditors.

\section{Research Method}

\subsection{Population and Sample}

The populations used in this study were all entities included in the financial services industry and listed on the Indonesia Stock Exchange. This study examined the dependent variables from 2016 to 2018 to obtain actual results by determining the previous three years' specifications and financial statement data, starting from 2014.

\section{Table 1}

Research Population and Sample

\begin{tabular}{lll}
\hline No. & Determination of the sample & Number \\
\hline 1 & Companies listed on the Financial Industry on the IDX from 2016-2018 & 266 \\
2 & Companies that do not use Specialist Public Accounting Firms & 175 \\
3 & Companies that do not use Seasoned Specialist Public Accounting Firms & 0 \\
4 & Companies that do not provide all the needed data & 11 \\
\hline & Total & 80 \\
\hline
\end{tabular}

\subsection{Variable Measurements}

\subsubsection{Audit Quality}

This study's dependent variable is audit quality, which is defined as the probability of an auditor to detect and disclose violations committed by clients in their accounting system (DeAngelo, 1981). Furthermore, this study used DLLP as a proxy for audit quality. The DLLP value used in the analysis is an absolute value, with low audit quality following the model developed by Kanagaretnam et al. (2004). In determining the DLLP, the first step taken was to determine LLP estimation with statistical tools to obtain a regression coefficient to calculate the non-discretionary loan loss provision (NDLLP). The LLP estimates are calculated using the following formula:

$$
L L P=\alpha_{1}+\beta_{1} N P L_{t-1}+\beta_{2} \Delta N P K L_{t}+\beta_{3} \Delta T L_{t}+\varepsilon
$$

In Eq. (1), the independent variable explains the NDLLP component to obtain the residual value's discretionary component (DLLP). 


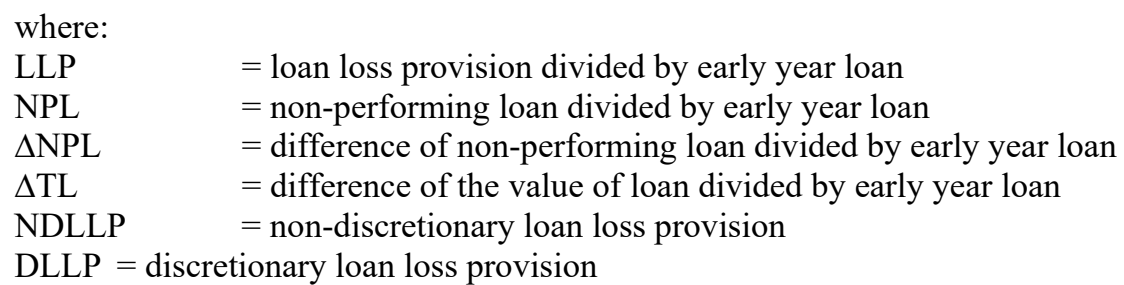

\subsubsection{Audit Specialist}

Specialist auditors are defined as companies with a more significant market share than their competitors in that particular industry (Neal dan Riley Jr, 2004). The industry's specialist auditors are generally determined based on industry market share, calculated using different metrics, such as audit fees, total assets, and sales revenue (Garcia Blandon and ArgilesBosch, 2018). The audit specialization in this study was measured using a model by Fitriany et al. (2015) in accordance with the following formula:

$$
S P E C=\frac{\text { Number of AP clients in the industry }}{\text { Total of issuers }} \times \frac{\text { Average of asset of AP clients }}{\text { Average of asset of issuers }}
$$

AP is classified as a specialist, assuming it controls more than ten market shares. Furthermore, it is measured by applying a dummy. The AP included in the specialist, and non-specialist categories are rated 1 and 0.

\subsubsection{Audit Specialist Tenure}

The audit specialist tenure is the AP categorized as a specialist auditor based on a specific period (Gaver \& Utke, 2018). The specialist tenure variable is divided into two, consisting of seasoned and unseasoned specialists, according to a previous study carried out by Gaver and Utke (2018). Seasoned specialists are AP classified as specialists due to their simultaneous three years of experience. However, the unseasoned specialist is the AP classified as a specialist in the first year. Further, each variable is measured using a dummy.

\subsection{Regression Model}

The study's first hypothesis was carried out using the testing model with specialist partner auditors' effect on audit quality compared to the non-specialist. In this test, the specialists and non-specialist are rated 1 and 0 . The regression model used to test the first hypothesis is as follows:

$\left(\mathrm{H}_{1}\right)$ AUDIT QUALITY $=\alpha+\beta_{1}$ Specialist $+\beta_{2} \mathrm{ROA}+\beta_{3} \mathrm{DAR}+\beta_{4} \mathrm{NPM}+\varepsilon$.

The specialist variable was replaced by dividing the specialist auditor into seasoned and unseasoned. The second and third hypothesis testing models test seasoned and unseasoned specialist auditors' effect compared to non-specialist partners. In the second hypothesis, auditors classified as seasoned and non-specialist auditors are rated 1 and 0 . Like the third hypothesis, auditors classified as unseasoned specialists and non-specialist auditors are rated 1 and 0 . The regression models used to test the second and third hypotheses are as follows:

$\left(\mathrm{H}_{2}\right)$ AUDIT QUALITY $=\alpha+\beta_{1}$ Seasoned $+\beta_{2} \mathrm{ROA}+\beta_{3} \mathrm{DAR}+\beta_{4} \mathrm{NPM}+\varepsilon$

$\left(\mathrm{H}_{3}\right)$ AUDIT QUALITY $=\alpha+\beta_{1}$ Unseasoned $+\beta_{2} \mathrm{ROA}+\beta_{3} \mathrm{DAR}+\beta_{4} \mathrm{NPM}+\varepsilon$

Additional tests were conducted to examine whether the seasoned specialist partner's audit quality is higher than the unseasoned specialist. Auditors classified as seasoned specialists and non-specialist auditors are rated 1 and 0 . The regression model used to test the fourth hypothesis is as follows:

$$
\left(\mathrm{H}_{4}\right) \text { AUDIT QUALITY }=\alpha+\beta_{1} \text { Tenure }+\beta_{2} \mathrm{ROA}+\beta_{3} \mathrm{DAR}+\beta_{4} \mathrm{NPM}+\varepsilon
$$

\section{Result}

\subsection{Descriptive statistics}

Table 2 shows the descriptive statistics of the variables used in this study. For the dependent variable, the audit quality (ADQ) of financial services companies in Indonesia that are listed on the IDX are measured using the DLLP method to produce an average of -0.0000000000259 in ranges of -0.02686 to 0.07781 . For independent variables, the audit specialist (SPE) is a dummy variable 
with an average value of 0.675 , which means that $67.5 \%$ of Indonesia's financial services companies are listed on the IDX with specialist auditors. This research divides specialist variables into seasoned and unseasoned specialists.

Table 2

Descriptive statistics

\begin{tabular}{lllll}
\hline Variable & Min & Max & Mean & Std. Deviation \\
\hline AQ & -0.0267 & 0.0778 & -0.0000 & 0.0195 \\
SPE & 0.0000 & 1.0000 & 0.6750 & 0.4713 \\
ROA & 0.0013 & 0.1246 & 0.0180 & 0.0191 \\
DAR & 0.4310 & 0.9365 & 0.8257 & 0.0817 \\
NPM & 0.0141 & 1.4857 & 0.1687 & 0.1775 \\
\hline
\end{tabular}

This table shows the result of the descriptive statistic of each variable in this study. Using 80 samples of Financing Industry listed on ISE from 2016-2018.

\subsection{Correlations}

Table 3

Pearson correlations

\begin{tabular}{|c|c|c|c|c|c|}
\hline & ADQ & SPE & ROA & DAR & NPM \\
\hline ROA & $0.1922 *$ & 0.0245 & 1 & & \\
\hline NPM & -0.0920 & 0.0402 & $0.7599 * * *$ & 0.0604 & 1 \\
\hline
\end{tabular}
$1 \%$.

Table 3 shows the results of the univariate analysis using the Pearson correlation method. The matrix table shows that audit specialists negatively and significantly affect audit quality as measured by the DLLP with a Pearson coefficient of -0.1938 . This univariate result provides initial support for hypothesis 1 . The audit quality provided by specialists is higher than non-specialist auditors. The results of the Pearson correlation also show that there is no significant relationship among the independent variables. Therefore, they are free from multicollinearity problems.

\subsection{Test of $\mathrm{HI}$}

Columns 1 and 2 of Table 4 show the results of the audit specialist variable test on the audit quality. From this table, it can be seen that the specialist variable has a significant effect on audit quality at a t-value of $-1,744$ and $p<0.1$. This is consistent with the hypothesis (H1), which states that specialist partner auditors' audit quality is higher than non-specialist partner auditors'. In addition, they possess more knowledge and experience than non-specialist auditors. Auditors use this knowledge and ability to improve their competence in finding misstatements to increase the resulting audit quality. Therefore, assuming shareholders need a monitoring tool to monitor managers' behavior, they can use a specialist auditor's services. Minuttiand Meza (2013) stated that market share is not something that can be relied upon as a measure for audit specialists due to the low significant value of $10 \%$. When it is only seen from the auditor's market share, the researchers ignore the importance of the period needed to create an industry specialization (Gaver and Utke, 2018). Furthermore, this research classified specialist auditors into two categories: seasoned and unseasoned, separately tested in hypothesis (H2) and (H3).

Table 4

Specialist and Specialist Tenure Auditor Partner and Audit Quality

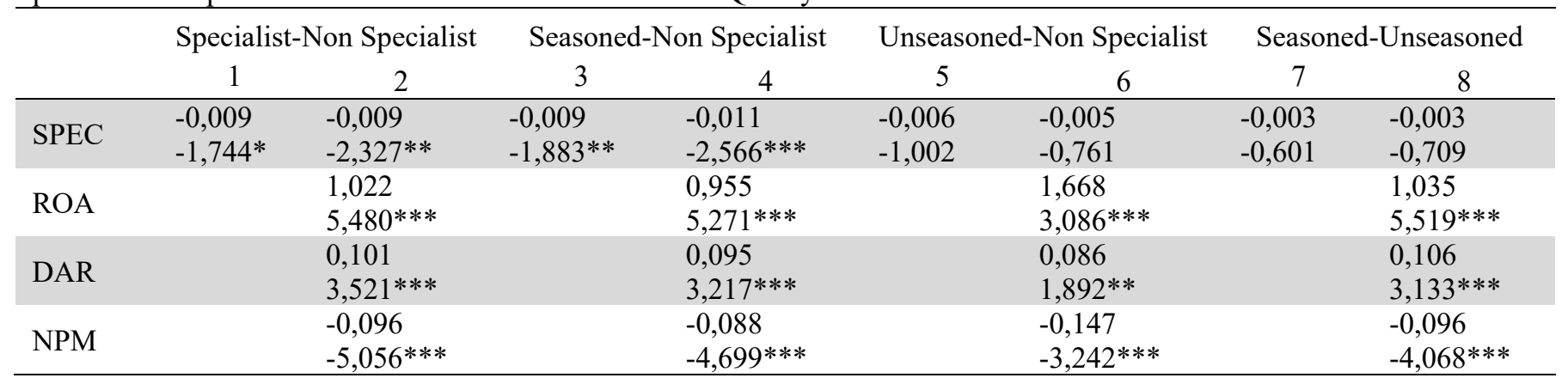




\subsection{Test of $\mathrm{H} 2$}

Testing the seasoned specialist auditor variable's effect on audit quality is presented in columns 3 and 4 of Table 4 . The table shows that the seasoned specialist variable significantly affects audit quality $(t=-1.883$ and $p<0.05)$. This is consistent with the hypothesis (H2), which stated that the audit quality provided by seasoned specialist partner auditors is higher than non-specialist partner auditors. Audit specialization is an ongoing process, which in practice is developed and validated continuously through the auditor's experience (Gendron et al., 2007). The longer the auditor is categorized as a specialist, the more experience and knowledge they possess in the industry.

Furthermore, the more competent the auditor is in an industry, the easier it is for them to find misstatements to improve the resulting audit quality. Therefore, assuming shareholders need better monitoring facilities than specialist auditors, they can use seasoned specialist auditors. This study supports the research carried out by Gaver and Utke (2018), which stated that seasoned specialist auditors' audit quality is higher than that of non-specialist auditors. Therefore, specialists' length of service needs to be tested in examining the relationship between the auditor's industry expertise and quality (Gaver \& Utke, 2018).

\subsection{Test of $\mathrm{H3}$}

Columns 5 and 6 of Table 4 show the unseasoned specialist auditor variable test results on audit quality. The results show that the unseasoned specialist variable has an insignificant effect on audit quality $(t=-1.002$ and $p>0.1)$. This is not in line with the hypothesis (H3), which stated that the audit quality provided by unseasoned specialist partner auditors is higher than that of nonspecialist partner auditors. Both unseasoned specialist auditors and non-specialist auditors have almost the same audit quality. This study also supports the research carried out by Gaver and Utke (2018), which stated that audit quality provided by unseasoned specialist auditors is not different from non-specialist auditors. They also stated that the audit quality provided by unseasoned specialist auditors is worse than non-specialist auditors. This is proofed by the positive and negative regression coefficient, which means that the audit quality provided by unseasoned specialist auditors is still better than that of non-specialist auditors.

\subsection{Test of $\mathrm{H} 4$}

The test results presented in columns 7 and 8 of Table 4 shows that the seasoned specialist variable has no significant effect on audit quality $(\beta=-0.601$ and $p>0.1)$. This is not in line with the hypothesis (H4), which stated that the audit quality provided by a seasoned specialist partner is higher than that provided by unseasoned partner auditors. However, the unseasoned specialist and non-specialist auditors have similar audit quality.

\section{Conclusion}

This study aimed to determine the effect of specialist auditors in an industry by considering the length of time required to become a specialist at the audit partner level. The results have shown that specialist auditors have higher audit quality compared to nonspecialist auditors. Furthermore, this study found evidence on auditors in the specialist seasoned category in accordance with their prolonged time of practice, with higher audit quality. This is in line with previous studies, which stated that auditors' audit quality in the unseasoned specialist category does not differ from that of non-specialist auditors. However, this study failed to determine the right evidence that seasoned specialist auditors are more qualified than unseasoned. This shows that there are inconsistent results between the hypothesis $\left(\mathrm{H}_{2}\right),\left(\mathrm{H}_{3}\right)$, and $\left(\mathrm{H}_{4}\right)$ that need to be reviewed in further research. Although this is the first research on specialist tenure at the audit partner level, it is limited to the audit quality provided by BIG4 auditors. Non-BIG4 auditors are outside the scope of this study because they are not included in the sampling criteria. Further research is needed to provide additional evidence on this topic that can examine the effect of specialist tenure on audit quality provided by BIG4 and Non-BIG4 auditors. This study has important implications that shareholders can use shareholders in selecting auditors to monitor managers' behavior to prevent agency conflict.

\section{References}

Arthur, N., Endrawes, M., \& Ho, S. (2017). Impact of Partner Change on Audit Quality: An Analysis of Partner and Firm Specialisation Effects. Australian Accounting Review, 27(4), 368-381.

Bae, G. S., Choi, S. U., \& Lee, J. E. (2018). Auditor Industry Specialization and Audit Pricing and Effort. Auditing: A Journal of Practice \& Theory, 38(1), 51-75.

Balsam, S., Krishnan, J., \& Yang, J. S. (2003). Auditor Industry Specialization and Earnings Quality. Auditing: A journal of practice \& Theory, 22(2), 71-97.

Beatty, A., \& Liao, S. (2014). Financial Accounting in the Banking Industry: A Review of the Empirical Literature. Journal of accounting and Economics, 58(2-3), 339-383.

Bowlin, K. O., Hobson, J. L., \& Piercey, M. D. (2015). The Effects of Auditor Rotation, Professional Skepticism, and Interactions with Managers on Audit Quality. The Accounting Review, 90(4), 1363-1393. 
DeAngelo, L. E. (1981). Auditor Independence, 'Low Balling,' and Disclosure Regulation. Journal of accounting and Economics, $3(2), 113-127$.

DeFond, M., \& Zhang, J. (2014). A Review of Archival Auditing Research. Journal of accounting and Economics, 58(2-3), 275326.

Febrianto, R., Dini, F., Audina, D., Yuskar, Y., \& Juita, V. (2017). The Influence of Pseudo Auditor Rotation on Audit Quality: New Evidence. Australasian Accounting, Business and Finance Journal, 11(4), 71-85.

Fitriany, F., Utama, S., Martani, D., \& Rosietta, H. (2015). Pengaruh Tenure, Rotasi dan Spesialisasi Kantor Akuntan Publik (KAP) terhadap Kualitas Audit: Perbandingan Sebelum dan Sesudah Regulasi Rotasi KAP di Indonesia. Jurnal Akuntansi dan Keuangan Universitas Kristen Petra, 17(1), 12-27.

Fitriany, F., Utama, S., Martani, D., \& Rosietta, H. (2016). Pengaruh Tenure, Rotasi dan Spesialisasi Kantor Akuntan Publik (KAP) Terhadap Kualitas Audit: Perbandingan Sebelum dan Sesudah Regulasi Rotasi KAP di Indonesia. Jurnal Akuntansi dan Keuangan, 17(1), 12-27.

Garcia-Blandon, J., \& Argiles-Bosch, J. M. (2018). Audit Partner Industry Specialization and Audit Quality: Evidence from Spain. International Journal of Auditing, 22(1), 98-108.

Gaver, J. J., \& Utke, S. (2018). Audit Quality and Specialist Tenure. The Accounting Review, 94(3), 113-147.

Gendron, Y., Cooper, D. J., \& Townley, B. (2007). The Construction of Auditing Expertise in Measuring Government Performance. Accounting, organizations and society, 32(1-2), 101-129.

Gul, F. A., Wu, D., \& Yang, Z. (2013). Do Individual Auditors Affect Audit Quality? Evidence from Archival data. The Accounting Review, 88(6), 1993-2023.

Gunn, J. L., \& Michas, P. N. (2017). Auditor Multinational Expertise and Audit Quality. The Accounting Review, 93(4), $203-224$.

Idawati, W. (2014). Effect of Audit Rotation, Audit Fee and Auditor Competence to Motivation Auditor and Implications on Audit Quality (Study in Registered Public Accountant Firms at Bank Indonesia). Audit Fee and Auditor Competence to Motivation Auditor and Implications on Audit Quality (Study in Registered Public Accountant Firms at Bank Indonesia)(May 27, 2014).

Jensen, M. C., \& Meckling, W. H. (1976). Theory of the firm: Managerial Behavior, Agency Costs and Ownership Structure. Journal of financial economics, 3(4), 305-360.

Jiang, J. X., Wang, I. Y., \& Wang, K. P. (2018). Big N Auditors and Audit Quality: New Evidence from Quasi-experiments. The Accounting Review.

Kamath, R., Huang, T.-C., \& Moroney, R. A. (2018). Auditor Rotation and Perceived Competence and Independence: The Effect of Fees and Industry Specialization. Journal of International Accounting Research, 17(3), 153-175.

Kanagaretnam, K., Lobo, G. J., \& Mathieu, R. (2004). Earnings Management to Reduce Earnings Variability: Evidence from Bank Loan Loss Provisions. Review of Accounting and Finance, 3(1), 128-148.

Kwon, S. Y., Park, J., \& Yu, J. (2017). The Effect of Industry-Specialist Auditors on SEO Underpricing Before and After the Global Financial Crisis. Auditing: A journal of practice \& Theory, 37(1), 89-113.

Lennox, C., Wu, X., \& Zhang, T. (2016). The Effect of Audit Adjustments on Earnings Quality: Evidence from China. Journal of accounting and Economics, 61(2-3), 545-562.

Minutti-Meza, M. (2013). Does Auditor Industry Specialization Improve Audit Quality? Journal of Accounting Research, 51(4), $779-817$.

Nadia, N. F. (2016). Pengaruh Tenur KAP, Reputasi KAP dan Rotasi KAP terhadap Kualitas Audit. Jurnal Akuntansi Bisnis, 13(26), 113-130.

Neal, T. L., \& Riley Jr, R. R. (2004). Auditor Industry Specialist Research Design. Auditing: A journal of practice \& Theory, 23(2), 169-177.

Nelson, M., \& Tan, H. T. (2005). Judgment and Decision Making Research in Auditing: A Task, Person, and Interpersonal Interaction Perspective. Auditing: A journal of practice \& Theory, 24(s-1), 41-71.

Nizar, A. A. (2017). Pengaruh Rotasi, Reputasi dan Spesialisasi Auditor terhadap Kualitas Audit (Studi Empiris pada Perusahaan Manufaktur yang Listed di BEI). Jurnal Ilmiah Akuntansi:Kompartemen, 15(2), 150-161.

Paramita, N. K. A., \& Latrini, N. M. Y. (2015). Pengaruh Ukuran Perusahaan, Umur Publikasi, Masa Perikatan Audit, Pergantian Manajemen Pada Kualitas Audit. E-Jurnal Akuntansi, 142-156.

Pramaswaradana, I. G. N. I., \& Astika, I. B. P. (2017). Pengaruh Audit Tenure, Audit Fee, Rotasi Auditor, Spesialsiasi Auditor, dan Umur Publikasi pada Kualitas Audit. E-Jurnal Akuntansi, 19(1), 168-194.

Romanus, R. N., Maher, J. J., \& Fleming, D. M. (2008). Auditor Industry Specialization, Auditor Changes, and Accounting Restatements. Accounting Horizons, 22(4), 389-413.

Siregar, Y., \& Elissabeth, D. M. (2018). Pengaruh Audit Tenure, Reputasi Auditor, Spesialisasi Audit, dan Ukuran Perusahaan terhadap Kualitas Audit pada Perusahaan Perbankan yang Terdaftar di Bursa Efek Indonesia (BEI). JURNAL ILMIAH SIMANTEK, 2(3), 168-194.

Solomon, I., Shields, M. D., \& Whittington, O. R. (1999). What Do Industry-Specialist Auditors Know? Journal of Accounting Research, 37(1), 191-208. 
(C) 2021 by the authors; licensee Growing Science, Canada. This is an open access article distributed under the terms and conditions of the Creative Commons Attribution (CC-BY) license (http://creativecommons.org/licenses/by/4.0/). 